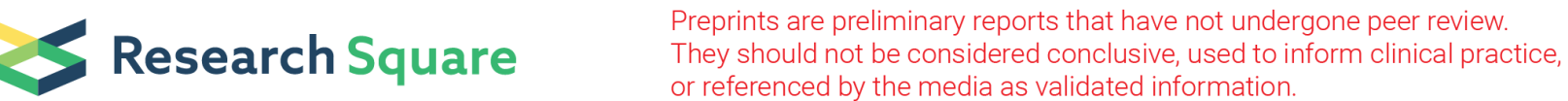

\section{LRP3, an apolipoprotein receptor that links reelin signalling and APP expression, is affected in Alzheimer's disease}

Inmaculada Cuchillo-lbañez ( $\square$ icuchillo@umh.es)

Instituto de Neurociencias https://orcid.org/0000-0002-3689-5518

Matthew P Lennol

IN Alicante: Instituto de Neurociencias

Sergio Escamilla

IN Alicante: Instituto de Neurociencias

Trinidad Mata-Balaguer

IN Alicante: Instituto de Neurociencias

Inmaculada López-Font

IN Alicante: Instituto de Neurociencias

Isidro Ferrer

Bellvitge University Hospital: Hospital Universitari de Bellvitge

Javier Saez-Valero

IN Alicante: Instituto de Neurociencias

\section{Research Article}

Keywords: sAPP, ApoER2, ApoER2-ICD, beta-amyloid

Posted Date: February 16th, 2021

DOl: https://doi.org/10.21203/rs.3.rs-220026/v1

License: (9) This work is licensed under a Creative Commons Attribution 4.0 International License. Read Full License 


\section{Abstract}

Background. Members of the low-density lipoprotein (LDL) receptor family are involved in endocytosis and in transducing signals, but also in APP (amyloid precursor protein) processing and $\beta$-amyloid secretion. ApoER2/LRP8 is a member of this family with key roles in synaptic plasticity in the adult brain. ApoER2 is cleaved after the binding of its ligand, the reelin protein, generating an intracellular domain (ApoER2-ICD) that modulates reelin gene transcription itself. In this work, we have analysed whether ApoER2-ICD is able to regulate the expression of other members of the LDL receptor family. We focused on LRP3, the most unknown member of the LDL receptor family, whose precise physiological role and potential participation in pathological processes such as Alzheimer's disease (AD) are still unknown.

Methods. The effects of full-length ApoER2 and ApoER2-ICD overexpression on protein levels, in presence of recombinant reelin or Ab42 peptide, were evaluated by a microarray, qRT-PCRs and western blots. The expression of LRP3 was analysed in human frontal cortex extracts from AD and non-demented subjects by $q$ RT-PCRs and western blot; and LRP3 interaction with other proteins was assessed by immunoprecipitation. In $\mathrm{CHO}$ cells overexpressing LRP3, protein levels of full-length APP and fragments were evaluated by western blots.

Results. We have identified that ApoER2 overexpression increases LRP3 expression. Stimulation of ApoER2 signaling by reelin increased LRP3 levels, and the same occurred following ApoER2-ICD overexpression. In human frontal cortex extracts we demonstrate that LRP3 interacts with apolipoprotein E and APP. In extracts from AD subjects, the levels of LRP3 mRNA and protein were lower than those in control subjects. Interestingly, LRP3 transfection in CHO-PS70 cells induced a decrease of fulllength APP levels and APP-CTF, and in the supernatant, levels of soluble APP fragments from the amyloidogenic (SAPPa) or non-amyloidogenic (SAPP 3 ) pathway, as well as A $\beta$ peptides, were drastically reduced respect to mock-transfected cells.

Limitations. There is a scarce knowledge of LRP3 physiological function as a neuronal receptor.

Conclusion. We describe that LRP3 expression is regulated via ApoER2/reelin signaling, and its levels are affected in AD; similarly to other LDL receptors, LRP3 is involved in APP expression.

\section{Introduction}

The members of the family of low-density lipoprotein (LDL) receptor are endocytic receptors that mediate the uptake of lipoproteins and have been classically studied for its role in cholesterol transport and metabolism. Robust evidences indicate that LDL receptor family members are involved in synaptic plasticity regulation and neuronal migration (extensively reviewed in [1-6]). LDL receptors are related to Alzheimer's disease (AD) pathogenesis as receptors of apolipoprotein $\mathrm{E}(\mathrm{apoE})$ [7], being the APOE4 variant the largest known genetic risk factor for late-onset sporadic AD [8,9]. Additionally, several members of the LDL receptors family are able to modulate the amyloid precursor (APP) proteolytic 
processing, either by regulation of the generation of the $\beta$-amyloid peptide $(A \beta)$ or through $A \beta$ clearance [10-13].

An important member of the LDL receptor family, ApoER2/LRP8, can exert a modulatory effect in transcriptional expression. ApoER2 interaction with its ligand, the reelin protein, drives to a sequential proteolytic processing, resulting in the cleavage of the receptor by a-secretase, that generates a membrane-tethered C-terminal fragment (ApoER2-CTF), followed by the cleavage by the $y$-secretase. The action of $y$-secretase generates an intracellular domain fragment (ApoER2-ICD) able to decrease the expression of reelin mRNA [14,15]. In brain extracts from AD subjects the generation of ApoER2-CTF appears lower and, accordingly, reelin expression results higher respect to those in control brain extracts [16].

In this study, we have explored further the modulatory transcriptional activity of ApoER2/reelin signalling, and we have observed that this pathway can modulate the expression of the LDL-related protein 3 (LRP3). LRP3 is probably the most unknown member of a new subfamily of LDL receptors [17], whose precise role in the central nervous system is still undetermined. We have explored LRP3 expression in Alzheimer's disease brain and after overexpression in $\mathrm{CHO}$ cells, and we have demonstrated that LRP3 is able to modulate APP expression, as are other members of LDL receptors family.

\section{Material And Methods}

\section{Human brain samples}

This study was approved by the ethics committee of Universidad Miguel Hernández de Elche, Spain, and it was carried out in accordance with the WMA Declaration of Helsinki. Brain samples (frontal cortex) were obtained from the Brain Bank of the Institute of Neuropathology, Bellvitge University Hospital. Lateonset $A D$ cases (12 females/18 males; average age $75 \pm 1$ years) were categorized according to the Braak stage of neurofibrillary tangle (NFT) pathology ([18]; Braak stage I-II $n=10$; Braak stage III-IV, $n=10$; Braak stage $\mathrm{V}-\mathrm{VI}, \mathrm{n}=10$ ). Special care was taken not to include cases with combined pathologies to avoid bias in the pathological series. Samples from non-demented (ND) controls (2 females/ 6 males; average age $52 \pm 7$ years) corresponded to individuals with no clinical dementia and no evidence of brain pathology. The mean post-mortem interval of the tissue was $\sim 8 \mathrm{~h}$ in all cases, with no significant difference between the groups.

\section{Brain membraneenriched fractions}

Brain cortex samples were homogenized using a polytron Heidolph RZR-1 at 600-800 rpm, in a glass potter applying 10-15 pulses in buffer at 10\% (w/v) (Hepes $1 \mathrm{mM}$, sucrose 0,32 $\mathrm{M}, \mathrm{Cl}_{2} \mathrm{Mg} \mathrm{mM} \mathrm{m}$, EDTA $1 \mathrm{mM}$, $\mathrm{NaHCO}_{3} 1 \mathrm{mM}, \mathrm{PMSF}$, protease inhibitors (Cocktail Complete EDTA free, Roche), antiphosphatase inhibitor (PhosSTOP, Sigma). The homogenized was centrifuged at $1000 \mathrm{x}$ g during 20 minutes at $4^{\circ} \mathrm{C}$. The supernatant (post-nuclear fraction) was centrifuged at $13000 \times \mathrm{g}$ during 15 minutes at $4^{\circ} \mathrm{C}$. The supernatant (cytosolic fraction) was aliquoted and the resulting pellet (membrane-enriched fraction) was 
resuspended in buffer (Hepes $1 \mathrm{mM}, \mathrm{Cl}_{2} \mathrm{Mg}$ mM, EDTA $1 \mathrm{mM}, \mathrm{NaHCO}_{3} 1 \mathrm{mM}, \mathrm{PMSF}$, protease inhibitor cocktail, antiphosphatase inhibitor).

\section{Cell cultures}

SH-SY5Y cells, a human neuroblastoma cell line, were seeded at a density of $1 \times 10^{5}$ cells/well in 6 -well plates and cultured in Dulbecco's Modified Eagle medium (DMEM) supplemented with Glutamax (GIBCO Thermo Fisher Scientific, Rockford, USA), 1\% heat-inactivated fetal bovine serum (FBS), penicillin (100 $\mathrm{U} / \mathrm{mL})$ and streptomycin $(100 \mu \mathrm{g} / \mathrm{mL})$ in a $5 \% \mathrm{CO}_{2}$ incubator. To neurodifferentiate the cells, $10 \mu \mathrm{M}$ alltrans-retinoic acid (RA, Sigma-Aldrich Co, MO, USA) in DMEM with 3\% FBS was added every 2 days. After 6 days, cells were treated with recombinant reelin, $12 \mu \mathrm{g} / \mathrm{ml}$ for 24 hours. Other cells were treated with suspensions of $\beta$-amyloid 1-42 $\left(A \beta_{42}\right)$ or scrambled control peptide (Aßsc;

AIAEGDSHVLKEGAYMEIFDVQGHVFGGKIFRVVDLGSHNVA) (both from Anaspec Peptide, Eurogentec) in DMEM with $1 \%$ FBS, for two consecutive days without changing the media, at a final concentration of 5 $\mu \mathrm{M}$.

Non differentiated SH-SY5Y cells were transfected with Lipofectamine 3000 (ThermoFisher) following manufacturer's instructions, with cDNA for the full-ApoER2 receptor, ApoER2-ICD and GFP/CDNA3.1 as mock-transfection as in [14] for $48 \mathrm{~h}$. After 24 hours, some cells were treated with recombinant reelin (12 $\mathrm{ug} / \mathrm{ml}$ ) for another 24 hours.

$\mathrm{CHO}$ cells stably over-expressing wild-type human APP (CHO-PS70, [19]) were grown in DMEM® containing 10\% FBS, 0.1\% Puromicin (Sigma-Aldrich) and 0.2\% G418 disulfate salt (Sigma-Aldrich). CHOPS70 cells were transfected with full-length LRP3 CDNA (a kind gift from Christine Lavoie, [20]) for $48 \mathrm{~h}$.

\section{Microarray analysis}

Gene expression was analysed $48 \mathrm{~h}$ after transfection with human full-length ApoER2, using microarrays SurePrint G3 Human Microarrays (ID 039494, Agilent Technologies, Spain) and performed by Bioarray SL (http://www.bioarray.es). The concentration and the purity of the total RNA extracted were measured by a NanoDrop spectrophotometer, and RNA quality was determined with the kit R6K Screen Tape (Agilent Technologies, Spain). The estimated RNA integrity number ranged between 9.5 and 9.7. Each sample (four samples and four controls) was labeled with Cy3 using the One-Color Microarray-Based Gene Expression Microarrays Analysis v.6.6 (Agilent Technologies, Spain). Data were imported to the linear models for microarray data Bioconductor software (Limma, Marray, affy, pcaMethods and EMA). Raw data were first subjected to background subtraction, then to within-array loess normalization. Finally, across-array normalization was performed. Normalized data were fitted to a linear model. The significance of the gene expression changes was analysed according to the adjusted $p$ value (adj. $p \square$ $0.05)$.

\section{qRT-PCR analysis}


RNA was extracted from human brains, SH-SY5Y cells or CHO-PS70 cells using the TRIzolß Reagent in the PureLinkÔ Micro-to-Midi Total RNA Purification System (Life Technologies, Carlsbad, CA, USA) following the manufacturer's instructions. SuperScriptÔ III Reverse Transcriptase (Life Technologies, Carlsbad, CA, USA) was used to synthesize cDNAs from this total RNA ( $2 \mu \mathrm{g})$ using random primers according to the manufacturer's instructions. Quantitative PCR amplification was performed on a StepOneÔ Real-Time PCR System (Applied Biosystems, Thermo Fisher Scientific, Rockford, USA) with TaqMan probes specific for human LRP3 (assay ID: HS01041220_m1), LDLR (assay ID:

HS00181192_m1), (Applied Biosystems, Thermo Fisher Scientific, Rockford, USA), and human 18S as a housekeeping gene (Applied Biosystems, Thermo Fisher Scientific, Rockford, USA) for human brain and SH-SYSH cells samples. In CHO-PS70, mRNA expression was measured with primers for human APP (forward: AACCAGTGACCATCCAGAAC; reverse: ACTTGTCAGGAACGAGAAGG), and for glyceraldehyde 3phosphate dehydrogenase (GAPDH, forward: AGAAGGTGGTGAAGCAGGCAT; reverse:

AGGTCCACCACTCTGTTGCTGT) to normalize the expression levels of the target gene by the $\Delta$ Ct method curves.

\section{Recombinant reelin}

HEK-293T cells stably transfected with reelin cDNA and GFP (mock) were grown in $175 \mathrm{~cm}^{2}$ flasks at a density of $10 \times 10^{6}$ cells / flask. After 3 days in culture with Optimem, the supernatants were filtered through $0.2 \mu \mathrm{m}$ pores and then concentrated by an Amicon Ultra size $100 \mathrm{kDa}$-filter of molecular exclusion (Millipore). For quantification, a coomasie gel was loaded with different volumes of the concentrated supernatants as well as with different bovine serum albumin solutions to perform an extrapolation.

\section{Western blotting}

Brain membrane-enriched fractions, SH-SY5Y extracts or CHO-PS70 extracts (30 $\mu \mathrm{g})$ were run on SDS$\operatorname{PAGE}(7.5 \%$, $12 \%$, precast $4-15 \%$ gradient, or Tris-tricine $16 \%)$ after boiling at $98^{\circ} \mathrm{C}$ for $5 \mathrm{~min}$ in $6 \times$ Laemmli sample buffer. Proteins were transferred by electrophoresis to nitrocellulose membranes and detected with antibodies against the C-terminal of LRP3 (mouse, 1:200, Sigma-Aldrich, St. Louis, MO, USA), N-terminal of LRP3 (rabbit, 1:100, Sigma-Aldrich, St. Louis, MO, USA), Flag (mouse, 1:1000, SigmaAldrich); C-terminal of LDLR (rabbit, 1:200, Sigma-Aldrich), C-terminal of ApoER2 (rabbit, 1: 2000, Abcam, Cambridge, UK), C-terminal of APP (rabbit, 1: 2000, Sigma-Aldrich), N-terminal of APP (rabbit, 1: 2000, Sigma-Aldrich) or a-tubulin (1:4000, Sigma-Aldrich) as a loading control. Primary antibody binding was visualized with fluorescently (IRDye) labeled secondary antibodies (1: 10000) and images were acquired using an Odyssey CLx Infrared Imaging system (LI-COR Biosciences GmbH).

\section{Immunoprecipitation}

Brain extracts $(200 \mu \mathrm{L})$ or CHO-PS170 extracts $(50 \mu \mathrm{L})$ were incubated on a roller for $2.5 \mathrm{~h}$ at room temperature with $100 \mu \mathrm{L}$ of magnetic beads (Dynabeads, Merk Millipore) coupled to either the N-terminal 
LRP3 (Sigma-Aldrich), reelin (Millipore), C-terminal APP (Sigma-Aldrich) or apoE (Sigma-Aldrich). The input, bound and unbound fractions were analyzed by western blotting.

\section{Immunofluorescence}

CHO-PS70 cells overexpressing LRP3-flag were washed with cold Hank-buffered salt solution and fixed with $4 \%$ paraformaldehyde and $0.1 \mathrm{M}$ EGTA for 10 minutes. Nonspecific sites were blocked with $10 \%$ $(\mathrm{w} / \mathrm{v})$ bovine serum albumin for 30 minutes. Cells were incubated with anti-LRP3 Ct (mouse; SigmaAldrich) for 1 hour followed by the secondary anti-body (Cy5 anti-rabbit; GE-Healthcare) for 1 hour. After 2 washes with PBS, cells were incubated briefly with Hoechst dye to label nuclei (Invitrogen). Pictures were acquired in a Leica SPEIl upright TCL-SL confocal microscope using an oil-immersion 40x objective.

\section{Statistical analysis}

The distribution of data was tested for normality using a D'Agostino-Pearson test. The data were analyzed using unpaired Student's t test (a Welch's correction was employed in data with different standard deviations) or Mann-Whitney test. The results are presented as the means \pm SE and all the analyses were performed using GraphPad Prism (Version 7; GraphPad Software, Inc). p value $<0.05$ was considered significant.

\section{Results}

\section{ApoER2 overexpression increases expression of LRP3, another lipoprotein receptor.}

SH-SY5Y cells were transfected with full-length ApoER2 and after 48 hours, a microarray was performed. Among the genes affected, we focused in the analysis of LDL receptors and apolipoprotein related genes (Table 1). The receptors LRP3 and LDLR appeared significantly upregulated, both members of the LDL receptors family. Upregulation of LRP3 was confirmed by $q R T-P C R$, with a significant increase in mRNA LRP3 level respect to its expression in non-transfected cells. However, increments in LDLR mRNA expression resulted not significant by qRT-PCR (Fig 1a).

Although SH-SY5Y cells secrete reelin to the media and it can act in a paracrine mode, recombinant reelin was employed to treat overexpressing-ApoER2 cells to potentiate the ApoER2 signaling. This treatment induced ApoER2 cleavage and consequently, reduced the amount of full-length ApoER2 and increased the generation of the ApoER2-CTF (Fig 1b). In retinoic acid neuro-differentiated SH-SY5Y cells, reelin treatment was also able to induce an increase in LRP3 protein levels respect to non-stimulated cells (Fig 1c).

\section{Expression of ApoER2-ICD upregulates LRP3 expression}

We considered the possibility that increments of LRP3 expression were induced by ApoER2-ICD, a fragment with transcriptional regulatory activity [14], generated by the proteolytic cleavage of ApoER2CTF. This small fragment was observed in ApoER2-overexpressing cells after treatment with reelin (Fig 
2a). Thus, we overexpressed a chimeric ApoER2-ICD (amino acid residues 728-842) and measured LRP3 expression. LRP3 mRNA expression and protein levels increased significantly respect to non-transfected cells (Fig 2b-d), while LDLR mRNA levels were not significantly affected by ApoER2-ICD (Fig 2e).

\section{Expression levels of LRP3 in Aß42-treated cells.}

Opposite to the upregulation of LRP3 mRNA and protein that we observed after overexpression of fulllength ApoER2 or ApoER2-ICD, we expected to find less LRP3 expression in AB42-treated cells, due to A $\beta$ treatment reduces the generation of ApoER2-CTF [16]. In agreement with this view, we found that A 342 treatment in neuro-differentiated SH-SY5Y cells decreased the LRP3 mRNA expression (Fig 3a) and LRP3 protein levels (Fig $\mathbf{3 b}$ ), respect to scrambled peptide-treatment.

\section{Expression levels of LRP3 in AD brain}

Next, we examined LRP3 levels in AD human frontal cortex extracts to explore whether this pathology affects its levels. In AD, LRP3 mRNA expression was lower respect to that in extracts from non-demented (ND) subjects (Fig 4a). When AD subjects were categorized by Braak stages to discriminate among neurodegenerative states, the reduction was significant only at Braak stages I-I; resulting close to be statistically significant at Braak III-IV and Braak V-VI (Fig 4b). To evaluate LRP3 protein levels in cortex from $A D$ and ND subjects, membrane-enriched fractions were isolated from brain samples and two antibodies were tested (Fig 4c). We found that LRP3 levels were lower in AD at Braak stages I-II in AD, compared to those in ND subjects (Fig 4d).

The estimated expression of LDLR mRNA was not significantly different between AD subjects and ND controls when the extracts were compared in overall, but neither when the comparison was performed among Braak stages nor by apoE genotype (Fig 4e).

\section{LRP3 interacts with apoE and APP, but not with reelin}

We evaluated by immunoprecipitation assays, whether reelin is as a ligand of LRP3, as it is of ApoER2, in frontal cortex extracts from control subjects and from AD subjects. However, reelin was not coimmunoprecipitated from any brain extracts. We next evaluated whether LRP3 interacts with apoE and APP, as it has been described in many members of the LDL receptors family. After immunoprecipitation, both proteins were co-immunoprecipitated with LRP3 in ND and AD cortex extracts (Fig 5).

\section{LRP3 modulates APP expression levels}

To test whether LRP3 is able to influence APP processing and A $\beta$ generation, we overexpressed LRP3 in CHO-PS70 cells, a cell line that express the wild-type APP770 isoform. LRP3 overexpression was located in the plasma membrane of CHO-PS70 cells, but it was also frequently observed in discrete areas in the soma (Fig 6a). LRP3 and APP co-immunoprecipitated in these cells (Fig 6b). 
Interestingly, LRP3 overexpression reduced drastically full-length APP levels, as well as APP-CTF in cell extracts. In the supernatant, the levels of sAPPa, SAPP $\beta$ and soluble A $\beta$ decreased in transfected $\mathrm{CHO}$ PS70 cells respect to mock (Fig $6 \mathrm{c}$ ). The decrease in APP levels was not related to a change in APP mRNA expression (Fig 6d).

\section{Discussion}

Our results suggest that reelin signaling, through the cleavage of its receptor ApoER2, can ultimately influence expression of other liporeceptors, such as LRP3. Many LDL receptor family members, as ApoER2, LDLR, LRP1, LRP1b, LRP6 and SorLA (LRP11), as well as other alternative apoE receptors such as Trem2, are $y$-secretase substrates $[21,22]$. For many of these receptor the nuclear translocation of the respective ICDs and their transcriptional functions have been demonstrated or inferred [13,23-25]. Here, we demonstrate that reelin-induced generation of ApoER2-ICD, as well as ApoER2-ICD overexpression, increase LRP3 expression. This supports a link between ApoER2 processing and the regulation of LRP3 protein levels.

In frontal cortex extracts from AD, where ApoER2/reelin signaling is impaired and ApoER2 processing is lessened (reviewed in [26]), we have found lower LRP3 protein and mRNA levels. LRP3 expression was mainly affected at early Braak stages of $A D$ (stages I-II), in which the transentorhinal region show neurofibrillary tangles and neuropil threads [18]. However, since the same decreasing trend was determined in later Braak stages, additional studies are needed to determine whether LRP3 decrease is only an early phenomenon associated to AD progression.

In the microarray, after overexpression of full-length ApoER2, the expression of another LDL receptors family member, LDLR, was also upregulated. Interestingly, both LRP3 and LDLR are encoded by genes located on chromosome 19, locus 19q13 [27,28]. The APOE gene also maps in chromosome 19, on locus 19q13.32 [29], in a cluster together with apolipoprotein C1 and C2 genes. Genetic linkage studies suggest the presence of $A D$ risk genes on chromosome 19, that would act in an independent manner from apoE, such as $A B C A 7$ (19p13.3) and CD33 (19q13.41) [30]. Indeed, LDLR was analyzed as a potential AD risk factor, but the study concluded that the genetic variants in LDLR did not make a significant contribution to $A D$ risk in the general population [31]. Interestingly, recent multiplex proteomics studies have identified that LDLR levels are modestly decreased in CSF from early AD patients, suggesting that this receptor can represent a new specific biomarkers of $A D$ [32]. Other genes encoding LDL receptors family members, such as LRP1, LRP1b, LRP2, LRP4, LRP6, and SorLA have been associated to AD risk (reviewed in [13]), even ApoER2 [33]. Despite the results from the microarray study, the qRT-PCR failed to corroborate the modulation of LDLR by ApoER2 and did not find changes on LDLR expression in AD extracts.

The reelin receptors ApoER2 and VDLR are core members of the LDL family that share the same extracellular domains structure, the ligand binding-type repeat domains (LBDs) and the EGF-precursor homology domains. The intracellular domain of each of the core members contain at least one NPxY (Asn-Pro-X-Tyr) motif, that functions in protein interaction/signal transduction [34-36] and endocytosis 
[37]. In comparison, LRP3 is smaller than the core members of the LDL receptors family. LRP3 belongs to a subfamily, together with LRP10 (murine LRP9), LRP12 and Lrad3 (ST7/Mig13). These subfamily members are characterized by the sole presence of LBDs and CUB-domains (which binds Complement, Uegf and Bmp1) in their extracellular domain, and lacks the EGF-like repeats [13]. The short LBD in LRP3 is likely the domain responsible of the co-immunoprecipitation of apoE, as this is the competent region to bind several ligands [38]. However, reelin was not co-immunoprecipitated, in the same manner as RAP (receptor-associated protein), another ApoER2 ligand, does not bind LRP3 neither $[17,27,39,40]$. In the intracellular domain, LRP3 lacks the NPxY motifs, but instead, contains a similar tyrosine-based sequence (EDFPVY) $[27,41]$. It is yet to be determined the domain by which APP is able to interact with LRP3. In vitro data showed that the extracellular domain of LRP10 interacts with APP [42], while Lrad3, the LDL receptor family member with the shortest extracellular domain [43] is also able to interact with APP and to modulate APP processing pathways. ApoER2 and APP are linked extracellularly by binding different domains of F-spondin [44] and intracellularly through the adaptor proteins Dab-1 and Fe65, that interact with the NPxY-motif of ApoER2 and APP [45-47]. Therefore, more studies are necessary to explore the interaction, either direct or indirect, between LRP3 and APP.

Core members of the LDL receptor family have been related to APP trafficking and internalization and, therefore, they could determine the APP proteolytic processing and A $\beta$ production, likely playing a role in $A D$ pathogenesis [48-51]. For example, LRP1 increases APP endocytosis and generation of A [52-54], while LRP1B retains APP at the cell surface [55]. ApoER2 is able to alter APP subcellular distribution, increasing the generation of $A \beta$; this effect depends on the integrity of the NPxY motif in ApoER2 [56]. Whereas in a mouse ApoER2 isoform that lacks three LBDs, predominates the non-amyloidogenic processing of APP [57]. Here, we observed that overexpression of LRP3 decreased the levels of full-length APP and APP fragments generated after amyloidogenic and non-amyloidogenic processing pathways, opening questions about the possible mechanism involved. A direct down-regulation of APP mRNA would be likely discharged as results of our QRT-PCR data. However, as with other LDL receptors [55], endocytic mechanisms could be involved in the alteration of APP processing, as LRP3 has been described as an endocytosis receptor [27]. In this line, LRP1 endocytosis impairment favours non-amyloidogenic processing of APP due to a reduced internalization, resulting in less extracellular $A \beta[59,60]$. Additionally, mechanisms related to the APP secretory pathway are also possible, as for LRP1 again, which retention in the endoplasmic reticulum by the expression of a specific motif, leads a decrease in full length APP and CTF levels at the plasma membrane as well as in $A \beta$ secretion $[1,61]$.

LRP3 highest expression is in skeletal muscle and ovary, but it is also present at relatively high levels in brain and heart, among other tissues [17]. LRP3 has been involved so far in osteogenic and adipocytic differentiation [62] and systemic use of steroids has been associated with site-specific differential methylation of the LRP3 gene [63], but its role in neuronal activity is still unknown. LRP3 has been identified as a gen up-regulated for a short window of two hours, exclusively following learning, in the rat dentate gyrus [64]. To clarify LRP3s biological functions it is essential to define the significance of LRP3 reduction in $A D$ frontal cortex that we have observed. An alteration in the expression of LRP3 may 
influence the processing and expression of APP, affecting its synaptic function, and therefore, contributing to this $A D$ pathology.

\section{Limitations}

The main limitation of this study is the scarce knowledge of the physiological function of LRP3 in the brain, as there are few reports about this as a neuronal receptor. We employed a well characterized brain collection, but it would be interesting to validate our finding with an alternative collection of post-mortem cortex samples from non-demented and AD subjects. Development of in vivo knockouts or knockdowns of LRP3 would contribute to the understanding of the mechanism that links this receptor and APP, given that, for example, knockdown of Lrp10 led to increased processing of APP to generate A [65].

\section{Conclusions}

ApoER2/reelin signalling is able to regulate LRP3 expression, and LRP3 reduces APP protein levels, including SAPP fragments and $A \beta$ peptide. The mechanism involved is yet to be determined, but this study could contribute to find new strategies in AD research, considering that LRP3 modulation could participate in the rising $A \beta$ levels.

\section{Abbreviations}

Aß42: $\beta$-amyloid protein (amino acid residues 1-42)

AD: Alzheimer's disease

APP: amyloid $\beta$ precursor protein

ApoE: apolipoprotein $\mathrm{E}$

ApoER2/LRP8: apolipoprotein E receptor 2

ApoER2-ICD: ApoER2 intracytoplasmic domain

ApoER2-CTF: ApoER2 C-terminal fragment

LDLR: low density lipoprotein receptor

ND: non-demented

VLDLR: very low-density lipoprotein receptor

\section{Declarations}


Funding (information that explains whether and by whom the research was supported) This work was supported by grants from the Fondo de Investigaciones Sanitarias (PI15/00665 and PI19-01359, cofunded by the Fondo Europeo de Desarrollo Regional, FEDER "Investing in your future"), and through CIBERNED (Instituto de Salud Carlos III, Spain). We also acknowledge financial support from the Spanish Ministerio de Economía y Competitividad, through the "Severo Ochoa" Programme for Centres of Excellence in R\&D (SEV-2017-0723).

Conflicts of interest/Competing interests: Not applicable

Availability of data and material (data transparency) All data and materials support their published claims and comply with field standards.

Code availability (software application or custom code) Not applicable

Authors' contributions Conceptualization: [Javier Saez-Valero and Inmaculada Cuchillo-lbáñez], Formal analysis and investigation: [Inmaculada Cuchillo-lbáñez, Matthew Lennol, Sergio Escamilla, Inmaculada López-Font, Trinidad Mata], Human brain source and analysis [Isidro Ferrer], Writing - original draft preparation: [Javier Saez-Valero and Inmaculada Cuchillo-lbáñez], Writing - review and editing: [All authors], Funding acquisition: [Javier Saez-Valero]

Ethics approval (include appropriate approvals or waivers) This study was approved by the ethics committee of Universidad Miguel Hernández de Elche, Spain, and it was carried out in accordance with the WMA Declaration of Helsinki.

Consent to participate (include appropriate statements) Not applicable

Consent for publication Not applicable

\section{Acknowledgements}

We thank Prof. T. Curran (Eppley Institute, University of Nebraska Medical Center, Omaha, USA), J. Nimpf (Max F., Department of Medical Biochemistry, Medical University of Vienna, Austria) and W. Rebeck (Georgetown University Medical Center, Washington, D.C., USA), and C. Lavoie (Department of Pharmacology and Physiology, University of Sherbrooke, Québec, Canada) for generously providing cDNAs. We thank Dr. E. Soriano and L. Pujadas (Department of Cell Biology, University of Barcelona, Barcelona, Spain) for providing HEK-293T cells stably transfected with reelin cDNA and GFP.

\section{Ethical standards}

The experiments comply with the current laws of the country in which they were performed, Spain.

\section{Conflict of interest}

The authors declare that they have no conflict of interest. 


\section{References}

1. Waldron E, Heilig C, Schweitzer A, Nadella N, Jaeger S, Martin AM, et al. LRP1 modulates APP trafficking along early compartments of the secretory pathway. Neurobiol Dis [Internet]. Neurobiol Dis; 2008 [cited 2020 Dec 27];31:188-97. Available from: https://pubmed.ncbi.nlm.nih.gov/18559293/

2. Gilat-Frenkel M, Boehm-Cagan A, Liraz O, Xian X, Herz J, Michaelson DM. Involvement of the Apoer2 and Lrp1 receptors in mediating the pathological effects of ApoE4 in vivo. Curr Alzheimer Res [Internet]. Bentham Science Publishers Ltd.; 2014 [cited 2020 Feb 13];11:549-57. Available from: http://www.ncbi.nlm.nih.gov/pubmed/24251389

3. Kim J, Yoon H, Basak J, Kim J. Apolipoprotein E in synaptic plasticity and alzheimer's disease: Potential cellular and molecular mechanisms [Internet]. Mol. Cells. Korean Society for Molecular and Cellular Biology; 2014 [cited 2020 Feb 13]. p. 833-40. Available from: http://www.ncbi.nlm.nih.gov/pubmed/25358504

4. Bock HH, May P. Canonical and non-canonical reelin signaling. Front Cell Neurosci [Internet]. Frontiers Media S.A.; 2016 [cited 2020 Feb 13];10:166. Available from: http://www.ncbi.nlm.nih.gov/pubmed/27445693

5. Lane-Donovan C, Herz J. Building a better blood-brain barrier. Elife [Internet]. eLife Sciences Publications Ltd; 2017 [cited 2020 Feb 13];6. Available from: http://www.ncbi.nlm.nih.gov/pubmed/28994392

6. May P, Herz J, Bock HH. Molecular mechanisms of lipoprotein receptor signalling [Internet]. Cell. Mol. Life Sci. Springer; 2005 [cited 2021 Jan 18]. p. 2325-38. Available from: https://link.springer.com/article/10.1007/s00018-005-5231-z

7. Herz J, Chen Y. Reelin, lipoprotein receptors and synaptic plasticity. Nat Rev Neurosci [Internet]. 2006 [cited 2019 Jul 23];7:850-9. Available from: http://www.ncbi.nlm.nih.gov/pubmed/17053810

8. Schmechel DE, Saunders AM, Strittmatter WJ, Crain BJ, Hulette CM, Joo SH, et al. Increased amyloid $\beta$-peptide deposition in cerebral cortex as a consequence of apolipoprotein $E$ genotype in late-onset Alzheimer disease. Proc Natl Acad Sci U S A. National Academy of Sciences; 1993;90:9649-53.

9. Pinto D, Delaby E, Merico D, Barbosa M, Merikangas A, Klei L, et al. Convergence of genes and cellular pathways dysregulated in autism spectrum disorders. Am J Hum Genet [Internet]. 2014 [cited 2019 Jan 14];94:677-94. Available from: https://linkinghub.elsevier.com/retrieve/pii/S0002929714001505

10. Jaeger S, Pietrzik CU. Functional role of lipoprotein receptors in Alzheimer's disease. Curr Alzheimer Res [Internet]. 2008 [cited 2020 Feb 13];5:15-25. Available from: http://www.ncbi.nlm.nih.gov/pubmed/18288927

11. Marzolo MP, Bu G. Lipoprotein receptors and cholesterol in APP trafficking and proteolytic processing, implications for Alzheimer's disease [Internet]. Semin. Cell Dev. Biol. Elsevier Ltd; 2009 [cited 2020 Feb 13]. p. 191-200. Available from: http://www.ncbi.nIm.nih.gov/pubmed/19041409 
12. Lane-Donovan C, Philips GT, Herz J. More than cholesterol transporters: lipoprotein receptors in CNS function and neurodegeneration. Neuron [Internet]. 2014 [cited 2020 Feb 13];83:771-87. Available from: http://www.ncbi.nlm.nih.gov/pubmed/25144875

13. Pohlkamp T, Wasser CR, Herz J. Functional roles of the interaction of APP and lipoprotein receptors [Internet]. Front. Mol. Neurosci. Frontiers Media S.A.; 2017 [cited 2020 Feb 13]. p. 54. Available from: http://www.ncbi.nlm.nih.gov/pubmed/28298885

14. Balmaceda V, Cuchillo-lbáñez I, Pujadas L, García-Ayllón M-S, Saura CA, Nimpf J, et al. ApoER2 processing by presenilin-1 modulates reelin expression. FASEB J. 2014;28.

15. Telese F, Ma Q, Perez PM, Notani D, Oh S, Li W, et al. LRP8-Reelin-Regulated Neuronal Enhancer Signature Underlying Learning and Memory Formation. Neuron [Internet]. Cell Press; 2015 [cited 2020 Feb 13];86:696-710. Available from: http://www.ncbi.nlm.nih.gov/pubmed/25892301

16. Mata-Balaguer T, Cuchillo-Ibañez I, Calero M, Ferrer I, Sáez-Valero J. Decreased generation of Cterminal fragments of ApoER2 and increased reelin expression in Alzheimer's disease. FASEB J [Internet]. 2018 [cited 2019 Jan 10];32:3536-46. Available from:

https://www.fasebj.org/doi/10.1096/fj.201700736RR

17. Battle MA, Maher VM, McCormick JJ. ST7 is a novel low-density lipoprotein receptor-related protein (LRP) with a cytoplasmic tail that interacts with proteins related to signal transduction pathways. Biochemistry [Internet]. 2003 [cited 2019 Feb 22];42:7270-82. Available from: http://pubs.acs.org/doi/abs/10.1021/bi034081y

18. Braak H, Braak E. Neuropathological stageing of Alzheimer-related changes. Acta Neuropathol [Internet]. 1991 [cited 2019 Jul 15];82:239-59. Available from:

http://www.ncbi.nlm.nih.gov/pubmed/1759558

19. Xia W, Zhang J, Kholodenko D, Citron M, Podlisny MB, Teplow DB, et al. Enhanced production and oligomerization of the 42-residue amyloid $\beta$ - protein by chinese hamster ovary cells stably expressing mutant presenilins. J Biol Chem [Internet]. American Society for Biochemistry and Molecular Biology; 1997 [cited 2020 Dec 26];272:7977-82. Available from: http://www-jbc.stanford.edu/jbc/

20. Brodeur J, Larkin H, Boucher R, Thériault C, St-Louis SC, Gagnon H, et al. Calnuc binds to LRP9 and affects its endosomal sorting. Traffic [Internet]. Blackwell Munksgaard; 2009 [cited 2020 Dec 26];10:1098-114. Available from: https://pubmed.ncbi.nlm.nih.gov/19497050/

21. Lleó A, Saura CA. Y-secretase substrates and their implications for drug development in Alzheimer's disease. Curr Top Med Chem [Internet]. 2011 [cited 2020 Feb 13];11:1513-27. Available from: http://www.ncbi.nlm.nih.gov/pubmed/21510835

22. Güner G, Lichtenthaler SF. The substrate repertoire of $\gamma$-secretase/presenilin. Semin. Cell Dev. Biol. Elsevier Ltd; 2020. p. 27-42.

23. Mi K, Johnson GVW. Regulated proteolytic processing of LRP6 results in release of its intracellular domain. J Neurochem [Internet]. 2007 [cited 2020 Feb 13];101:517-29. Available from: http://www.ncbi.nlm.nih.gov/pubmed/17326769 
24. May P, Woldt E, Matz RL, Boucher P. The LDL receptor-related protein (LRP) family: an old family of proteins with new physiological functions. Ann Med [Internet]. 2007 [cited 2020 Feb 13];39:219-28. Available from: http://www.ncbi.nlm.nih.gov/pubmed/17457719

25. Wakabayashi T, De Strooper B. Presenilins: Members of the $\gamma$-secretase quartets, but part-time soloists too [Internet]. Physiology. Physiology (Bethesda); 2008 [cited 2020 Dec 26]. p. 194-204. Available from: https://pubmed.ncbi.nlm.nih.gov/18697993/

26. Cuchillo-Ibañez I, Balmaceda V, Mata-Balaguer T, Lopez-Font I, Sáez-Valero J. Reelin in Alzheimer's Disease, Increased Levels but Impaired Signaling: When More is Less. J Alzheimer's Dis [Internet]. 2016 [cited 2019 Mar 28];52:403-16. Available from: http://www.medra.org/servlet/aliasResolver? alias=iospress\&doi=10.3233/JAD-151193

27. Ishii H, Kim D-H, Fujita T, Endo Y, Saeki S, Yamamoto TT. cDNA Cloning of a New Low-Density Lipoprotein Receptor-Related Protein and Mapping of Its Gene (LRP3) to Chromosome Bands 19q12-q13.2. Genomics [Internet]. 1998 [cited 2019 Feb 22];51:132-5. Available from: http://www.ncbi.nlm.nih.gov/pubmed/9693042

28. Francke U, Brown MS, Goldstein JL. Assignment of the human gene for the low density lipoprotein receptor to chromosome 19: Synteny of a receptor, a ligand, and a genetic disease. Proc Natl Acad Sci U S A. 1984;81:2826-30.

29. Shaw DJ, Brook JD, Meredith AL, Harley HG, Sarfarazi M, Harper PS. Gene mapping and chromosome 19. J Med Genet [Internet]. 1986 [cited 2020 Feb 14];23:2-10. Available from: http://www.ncbi.nlm.nih.gov/pubmed/3081724

30. Moreno-Grau S, Hernández I, Heilmann-Heimbach S, Ruiz S, Rosende-Roca M, Mauleón A, et al. Genome-wide significant risk factors on chromosome 19 and the APOE locus. Oncotarget [Internet]. Impact Journals LLC; 2018 [cited 2020 Feb 14];9:24590-600. Available from: http://www.ncbi.nlm.nih.gov/pubmed/29872490

31. Bertram L, Hsiao M, McQueen MB, Parkinson M, Mullin K, Blacker D, et al. The LDLR locus in alzheimer's disease: A family-based study and meta-analysis of case-control data. Neurobiol Aging [Internet]. Elsevier Inc.; 2007 [cited 2020 Feb 14];28:18.e1-18.e4. Available from: http://www.ncbi.nlm.nih.gov/pubmed/16378661

32. Whelan CD, Mattsson N, Nagle MW, Vijayaraghavan S, Hyde C, Janelidze S, et al. Multiplex proteomics identifies novel CSF and plasma biomarkers of early Alzheimer's disease. Acta Neuropathol Commun [Internet]. BioMed Central Ltd.; 2019 [cited 2020 Feb 14];7:169. Available from: http://www.ncbi.nlm.nih.gov/pubmed/31694701

33. Ma SL, Ng HK, Baum L, Pang JCS, Chiu HFK, Woo J, et al. Low-density lipoprotein receptor-related protein 8 (apolipoprotein E receptor 2) gene polymorphisms in Alzheimer's disease. Neurosci Lett. Elsevier Ireland Ltd; 2002;332:216-8.

34. Trommsdorff M, Borg JP, Margolis B, Herz J. Interaction of cytosolic adaptor proteins with neuronal apolipoprotein E receptors and the amyloid precursor protein. J Biol Chem [Internet]. J Biol Chem; 1998 [cited 2020 Dec 20];273:33556-60. Available from: https://pubmed.ncbi.nlm.nih.gov/9837937/ 
35. Howell BW, Lanier LM, Frank R, Gertler FB, Cooper JA. The Disabled 1 Phosphotyrosine-Binding Domain Binds to the Internalization Signals of Transmembrane Glycoproteins and to Phospholipids. Mol Cell Biol [Internet]. American Society for Microbiology; 1999 [cited 2020 Dec 20];19:5179-88. Available from: https://pubmed.ncbi.nlm.nih.gov/10373567/

36. Gotthardt M, Trommsdorff M, Nevitt MF, Shelton J, Richardson JA, Stockinger W, et al. Interactions of the low density lipoprotein receptor gene family with cytosolic adaptor and scaffold proteins suggest diverse biological functions in cellular communication and signal transduction. J Biol Chem. 2000;275:25616-24.

37. Chen WJ, Goldstein JL, Brown MS. NPXY, a sequence often found in cytoplasmic tails, is required for coated pit-mediated internalization of the low density lipoprotein receptor. J Biol Chem. 1990;265:3116-23.

38. Croy JE, Shin WD, Knauer MF, Knauer DJ, Komives EA. All three LDL receptor homology regions of the LDL receptor-related protein bind multiple ligands. Biochemistry [Internet]. 2003 [cited 2019 Feb 22];42:13049-57. Available from: http://pubs.acs.org/doi/abs/10.1021/bi034752s

39. Divekar SD, Burrell TC, Lee JE, Weeber EJ, Rebeck GW. Ligand-induced homotypic and heterotypic clustering of apolipoprotein E Receptor 2. J Biol Chem [Internet]. American Society for Biochemistry and Molecular Biology Inc.; 2014 [cited 2020 Dec 20];289:15894-903. Available from: https://pubmed.ncbi.nlm.nih.gov/24755222/

40. Croy JE, Shin WD, Knauer MF, Knauer DJ, Komives EA. All Three LDL Receptor Homology Regions of the LDL Receptor-Related Protein Bind Multiple Ligands. Biochemistry. Biochemistry; 2003;42:13049-57.

41. Boucher R, Larkin H, Brodeur J, Gagnon $H$, Thériault C, Lavoie C. Intracellular trafficking of LRP9 is dependent on two acidic cluster/dileucine motifs. Histochem Cell Biol [Internet]. Springer Verlag; 2008 [cited 2020 Aug 6];130:315-27. Available from: https://pubmed.ncbi.nlm.nih.gov/18461348/

42. Brodeur J, Thériault C, Lessard-Beaudoin M, Marcil A, Dahan S, Lavoie C. LDLR-related protein 10 (LRP10) regulates amyloid precursor protein (APP) trafficking and processing: Evidence for a role in Alzheimers disease. Mol Neurodegener [Internet]. Mol Neurodegener; 2012 [cited 2020 Dec 20];7. Available from: https://pubmed.ncbi.nlm.nih.gov/22734645/

43. Ranganathan S, Noyes NC, Migliorini M, Winkles JA, Battey FD, Hyman BT, et al. LRAD3, a novel lowdensity lipoprotein receptor family member that modulates amyloid precursor protein trafficking. $J$ Neurosci [Internet]. J Neurosci; 2011 [cited 2020 Dec 26];31:10836-46. Available from: https://pubmed.ncbi.nlm.nih.gov/21795536/

44. Ho A, Südhof TC. Binding of F-spondin to amyloid- $\beta$ precursor protein: A candidate amyloid- $\beta$ precursor protein ligand that modulates amyloid- $\beta$ precursor protein cleavage. Proc Natl Acad Sci U S A. 2004;101:2548-53.

45. Hoe H-S, Wessner D, Beffert U, Becker AG, Matsuoka Y, Rebeck GW. F-spondin interaction with the apolipoprotein E receptor ApoEr2 affects processing of amyloid precursor protein. Mol Cell Biol 
[Internet]. 2005 [cited 2020 Feb 14];25:9259-68. Available from:

http://www.ncbi.nlm.nih.gov/pubmed/16227578

46. May P, Krishna Reddy Y, Herz J. Proteolytic processing of low density lipoprotein receptor-related protein mediates regulated release of its intracellular domain. J Biol Chem [Internet]. J Biol Chem; 2002 [cited 2020 Aug 4];277:18736-43. Available from:

https://pubmed.ncbi.nlm.nih.gov/11907044/

47. Hoe HS, Tran TS, Matsuoka Y, Howell BW, Rebeck GW. DAB1 and reelin effects on amyloid precursor protein and ApoE receptor 2 trafficking and processing. J Biol Chem [Internet]. JBC Papers in Press; 2006 [cited 2020 Dec 20];281:35176-85. Available from: http://www.jbc.org/

48. Kounnas MZ, Moir RD, Rebeck GW, Bush Al, Argraves WS, Tanzi RE, et al. LDL receptor-related protein, a multifunctional ApoE receptor, binds secreted $\beta$-amyloid precursor protein and mediates its degradation. Cell. 1995;82:331-40.

49. Bu G, Cam J, Zerbinatti C. LRP in amyloid-beta production and metabolism. Ann N Y Acad Sci [Internet]. 2006 [cited 2020 Feb 14];1086:35-53. Available from:

http://www.ncbi.nlm.nih.gov/pubmed/17185504

50. Holtzman DM, Herz J, Bu G. Apolipoprotein E and apolipoprotein E receptors: normal biology and roles in Alzheimer disease. Cold Spring Harb Perspect Med [Internet]. Cold Spring Harbor Laboratory Press; 2012 [cited 2020 Feb 14];2:a006312. Available from:

http://www.ncbi.nlm.nih.gov/pubmed/22393530

51. Zhang H, Chen W, Tan Z, Zhang L, Dong Z, Cui W, et al. A role of low-density lipoprotein receptorrelated protein 4 (LRP4) in astrocytic A $\beta$ clearance. J Neurosci [Internet]. Society for Neuroscience; 2020 [cited 2020 Jul 30];40:JN-RM-0250-20. Available from:

https://pubmed.ncbi.nlm.nih.gov/32457076/

52. Ulery PG, Beers J, Mikhailenko I, Tanzi RE, Rebeck GW, Hyman BT, et al. Modulation of $\beta$-amyloid precursor protein processing by the low density lipoprotein receptor-related protein (LRP). Evidence that LRP contributes to the pathogenesis of Alzheimer's disease. J Biol Chem. 2000;275:7410-5.

53. Pietrzik CU, Busse T, Merriam DE, Weggen S, Koo EH. The cytoplasmic domain of the LDL receptorrelated protein regulates multiple steps in APP processing. EMBO J. 2002;21:5691-700.

54. Cam JA, Zerbinatti C V, Li Y, Bu G. Rapid endocytosis of the low density lipoprotein receptor-related protein modulates cell surface distribution and processing of the beta-amyloid precursor protein. $\mathrm{J}$ Biol Chem [Internet]. 2005 [cited 2020 Feb 14];280:15464-70. Available from: http://www.ncbi.nlm.nih.gov/pubmed/15705569

55. Cam JA, Zerbinatti C V, Knisely JM, Hecimovic S, Li Y, Bu G. The low density lipoprotein receptorrelated protein $1 \mathrm{~B}$ retains beta-amyloid precursor protein at the cell surface and reduces amyloid-beta peptide production. J Biol Chem [Internet]. 2004 [cited 2020 Feb 14];279:29639-46. Available from: http://www.ncbi.nlm.nih.gov/pubmed/15126508

56. Fuentealba RA, Barría MI, Lee J, Cam J, Araya C, Escudero CA, et al. ApoER2 expression increases Abeta production while decreasing Amyloid Precursor Protein (APP) endocytosis: Possible role in the 
partitioning of APP into lipid rafts and in the regulation of gamma-secretase activity. Mol Neurodegener [Internet]. 2007 [cited 2020 Feb 14];2:14. Available from:

http://www.ncbi.nlm.nih.gov/pubmed/17620134

57. Goto JJ, Tanzi RE. The role of the low-density lipoprotein receptor-related protein (LRP1) in Alzheimer's A $\beta$ generation: Development of a cell-based model system. J Mol Neurosci [Internet]. Humana Press; 2002 [cited 2020 Apr 2];19:37-41. Available from:

http://www.ncbi.nlm.nih.gov/pubmed/12212791

58. Pohlkamp T, Wasser CR, Herz J. Functional roles of the interaction of APP and lipoprotein receptors [Internet]. Front. Mol. Neurosci. Frontiers Media S.A.; 2017 [cited 2020 Aug 2]. Available from: /pmc/articles/PMC5331069/?report=abstract

59. Van Gool B, Storck SE, Reekmans SM, Lechat B, Gordts PLSM, Pradier L, et al. LRP1 Has a Predominant Role in Production over Clearance of $A \beta$ in a Mouse Model of Alzheimer's Disease. Mol Neurobiol [Internet]. Humana Press Inc.; 2019 [cited 2020 Dec 28];56:7234-45. Available from: https://pubmed.ncbi.nlm.nih.gov/31004319/

60. Eggert S, Gonzalez AC, Thomas C, Schilling S, Schwarz SM, Tischer C, et al. Dimerization leads to changes in APP (amyloid precursor protein) trafficking mediated by LRP1 and SorLA. Cell Mol Life Sci [Internet]. Birkhauser Verlag AG; 2018 [cited 2021 Jan 18];75:301-22. Available from: https://pubmed.ncbi.nlm.nih.gov/28799085/

61. Herr UM, Strecker P, Storck SE, Thomas C, Rabiej V, Junker A, et al. LRP1 modulates APP intraneuronal transport and processing in its monomeric and dimeric state. Front Mol Neurosci [Internet]. Frontiers Research Foundation; 2017 [cited 2020 Dec 27];10. Available from: https://pubmed.ncbi.nlm.nih.gov/28496400/

62. Elsafadi M, Manikandan M, Alajez NM, Hamam R, Dawud RA, Aldahmash A, et al. MicroRNA-4739 regulates osteogenic and adipocytic differentiation of immortalized human bone marrow stromal cells via targeting LRP3. Stem Cell Res [Internet]. 2017 [cited 2020 Feb 14];20:94-104. Available from: http://www.ncbi.nlm.nih.gov/pubmed/28340487

63. Wan ES, Qiu W, Baccarelli A, Carey VJ, Bacherman H, Rennard SI, et al. Systemic steroid exposure is associated with differential methylation in chronic obstructive pulmonary disease. Am J Respir Crit Care Med [Internet]. 2012 [cited 2020 Feb 14];186:1248-55. Available from: http://www.ncbi.nlm.nih.gov/pubmed/23065012

64. O'Sullivan NC, McGettigan PA, Sheridan GK, Pickering M, Conboy L, O'Connor JJ, et al. Temporal change in gene expression in the rat dentate gyrus following passive avoidance learning. $J$ Neurochem [Internet]. 2007 [cited 2020 Feb 14];101:1085-98. Available from: http://www.ncbi.nlm.nih.gov/pubmed/17298388

65. Brodeur J, Thériault C, Lessard-Beaudoin M, Marcil A, Dahan S, Lavoie C. LDLR-related protein 10 (LRP10) regulates amyloid precursor protein (APP) trafficking and processing: Evidence for a role in Alzheimers disease. Mol Neurodegener [Internet]. Mol Neurodegener; 2012 [cited 2020 Jul 30];7. Available from: https://pubmed.ncbi.nlm.nih.gov/22734645/ 
66. Grote A, Robens BK, Blümcke I, Becker AJ, Schoch S, Gembé E. LRP12 silencing during brain development results in cortical dyslamination and seizure sensitization. Neurobiol Dis. Academic Press Inc.; 2016;86:170-6.

\section{Tables}

Table 1. Expression of genes up-regulated by full-length ApoER2 overexpression.

\begin{tabular}{|c|c|c|c|c|c|}
\hline \multicolumn{6}{|c|}{ Genomic } \\
\hline Symbol & Gene Name & location & Function & $\log \mathrm{FC}$ & $\operatorname{adj} p$ \\
\hline \multirow[t]{3}{*}{ LRP3 } & $\begin{array}{l}\text { low density lipoprotein } \\
\text { receptor-related protein } 3\end{array}$ & $19 q 13.11$ & $\begin{array}{l}\text { Internalization of } \\
\text { lipophilic molecules }\end{array}$ & & 0,047 \\
\hline & & & $\begin{array}{l}\text { and/or signal } \\
\text { transduction }\end{array}$ & 0,48 & \\
\hline & & & Precise role is unclear & & \\
\hline LDLR & $\begin{array}{l}\text { low density lipoprotein } \\
\text { receptor }\end{array}$ & 19p13.2 & $\begin{array}{l}\text { Mediates endocytosis of } \\
\text { cholesterol-rich LDL }\end{array}$ & 0,43 & 0,018 \\
\hline APOL1 & apolipoprotein L, 1 & $22 q 12.3$ & $\begin{array}{l}\text { Minor apoprotein } \\
\text { component of HDL }\end{array}$ & 1,28 & 0,003 \\
\hline INSIG1 & insulin induced gene 1 & $7 q 36.3$ & $\begin{array}{l}\text { Regulation of cholesterol } \\
\text { cell concentration }\end{array}$ & 0,72 & 0,001 \\
\hline DHCR24 & $\begin{array}{l}\text { 24-dehydrocholesterol } \\
\text { reductase }\end{array}$ & $1 \mathrm{p} 32.3$ & $\begin{array}{l}\text { Cholesterol metabolic } \\
\text { process }\end{array}$ & 0,35 & 0,008 \\
\hline MVK & mevalonate kinase & $12 q 24.11$ & $\begin{array}{l}\text { Cholesterol metabolic } \\
\text { process }\end{array}$ & 0,33 & 0,019 \\
\hline ApoE & apolipoprotein E & $19 q 13.32$ & Cholesterol transport & 0.03 & 0.81 \\
\hline
\end{tabular}

Table 1. Genes associated with lipid binding and transport, and cholesterol metabolism, whose transcripts were upregulated in ApoER2 overexpressing SH-SY5Y cells compared with control cells transfected with an empty vector. The expression of the genes was analyzed on DNA microarrays. The fold change $(\log F C)$ in gene expression between samples and controls, as well the adj $p$ ( $p$-value adjusted for multiple testing) is indicated.

\section{Figures}


A
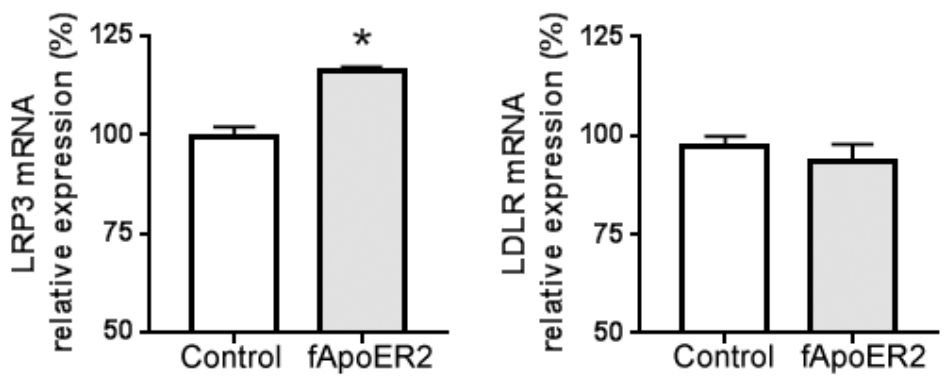

B
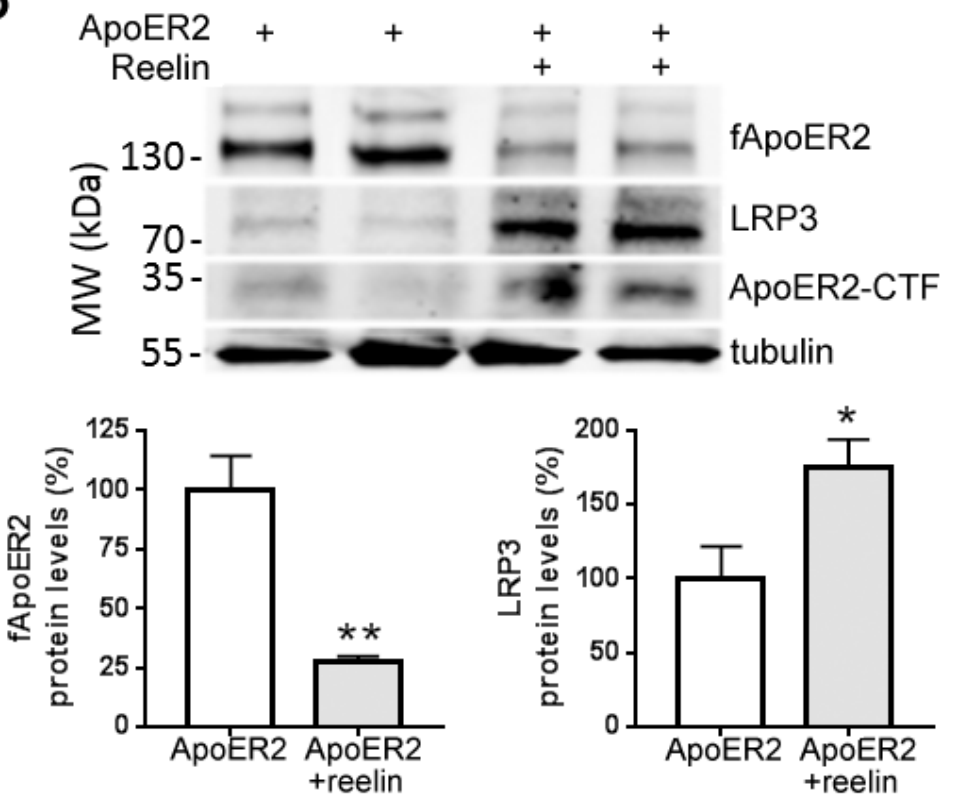

C
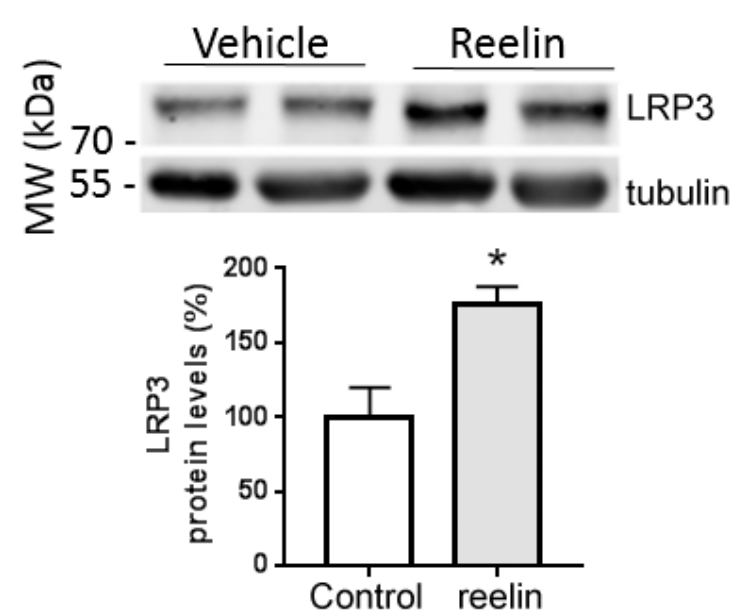

Figure 1

ApoER2/reelin signaling upregulates LRP3 expression. a) qRT-PCR analysis showing expression of LRP3 mRNA and LDLR mRNA after transfection with GFP cDNA (Control) and full-length ApoER2 cDNA (fApoER2) in SH-SYSH cells. 18S was used as an internal control for mRNA expression ( $n=10-12$ for each condition, $p<0.001$ for control versus fApoER2; T-test with Welch's correction). Note that $X$ axes begins at $50 \%$ b) Quantification and western blot showing the expression of full-length ApoER2, ApoER2-CTF 
and LRP3 proteins after fApoER2 transfection and reelin $(12 \mu \mathrm{g} / \mathrm{ml})$ treatment for 24 hours in SH-SYSH cells. Tubulin was used as an internal control ( $n=9$ for each condition, $* \star p<0.001$ for expression of fApoER2, T-test with Welch's correction, * $p<0.05$ for expression of LRP3, T-test). c) Quantification and western blot showing the expression of full-length ApoER2 and LRP3 proteins after reelin $(12 \mu \mathrm{g} / \mathrm{ml})$ treatment for 24 hours or vehicle (Hanks's media) in neuro-differentiated SH-SY5Y cells with retinoic acid ( $n=9$ for each condition, ${ }^{*} p<0.05$ T-test).
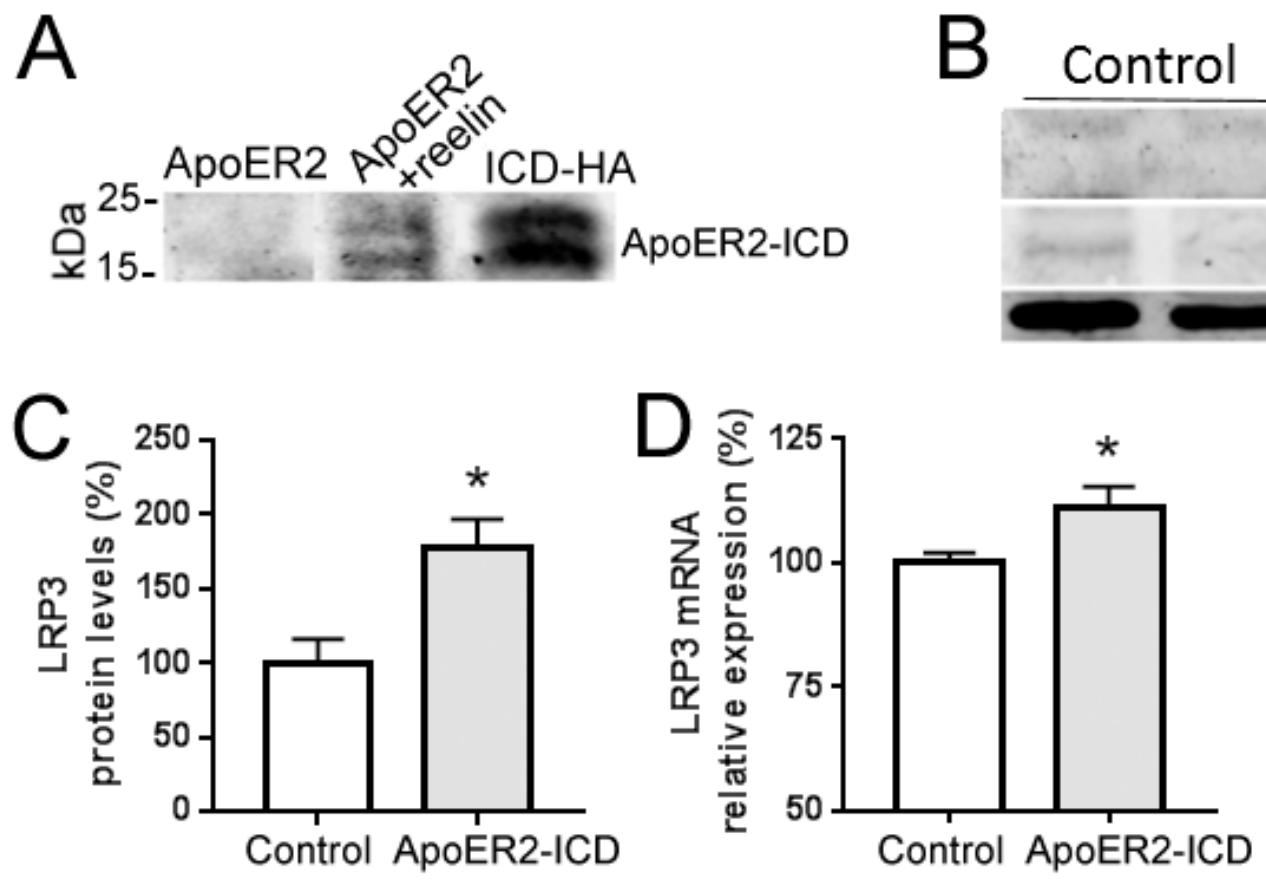

ApoER2-ICD
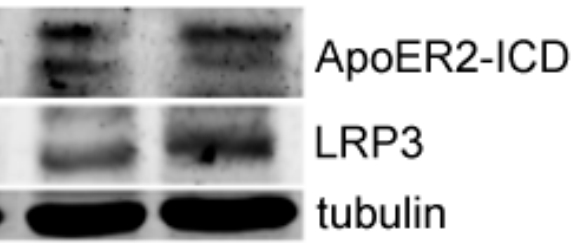

\section{Figure 2}

ApoER2-ICD increases LRP3 expression. a) Representative western blot showing the expression of ApoER2-ICD after transfection with full-length ApoER2 CDNA (ApoER2) and reelin treatment $(12 \mu \mathrm{g} / \mathrm{ml}$, ApoER2 + reelin) for 24 hours in SH-SYSH cells. For comparison, it is also shown the expression of the ApoER2-ICD construct (ApoER2-ICD). b) Western blot and c) quantification of LRP3 protein expression after ApoER2-ICD transfection in SH-SYSH cells. Tubulin was used as an internal control $(n=6$ for each condition, ${ }^{*} p<0.001$, T-test). d) qRT-PCR analysis showing expression of LRP3 mRNA ( $n=7$ for each condition, ${ }^{*} p<0.05$, T-test) and e) LDLR mRNA ( $n=10$ for each condition) after transfection with GFP cDNA (control) and ApoER2-ICD cDNA in SH-SYSH cells. Note that $X$ axe in fig $2 \mathrm{~d}$ begins at $50 \%$. $18 \mathrm{~s}$ was used as an internal control for mRNA expression. 


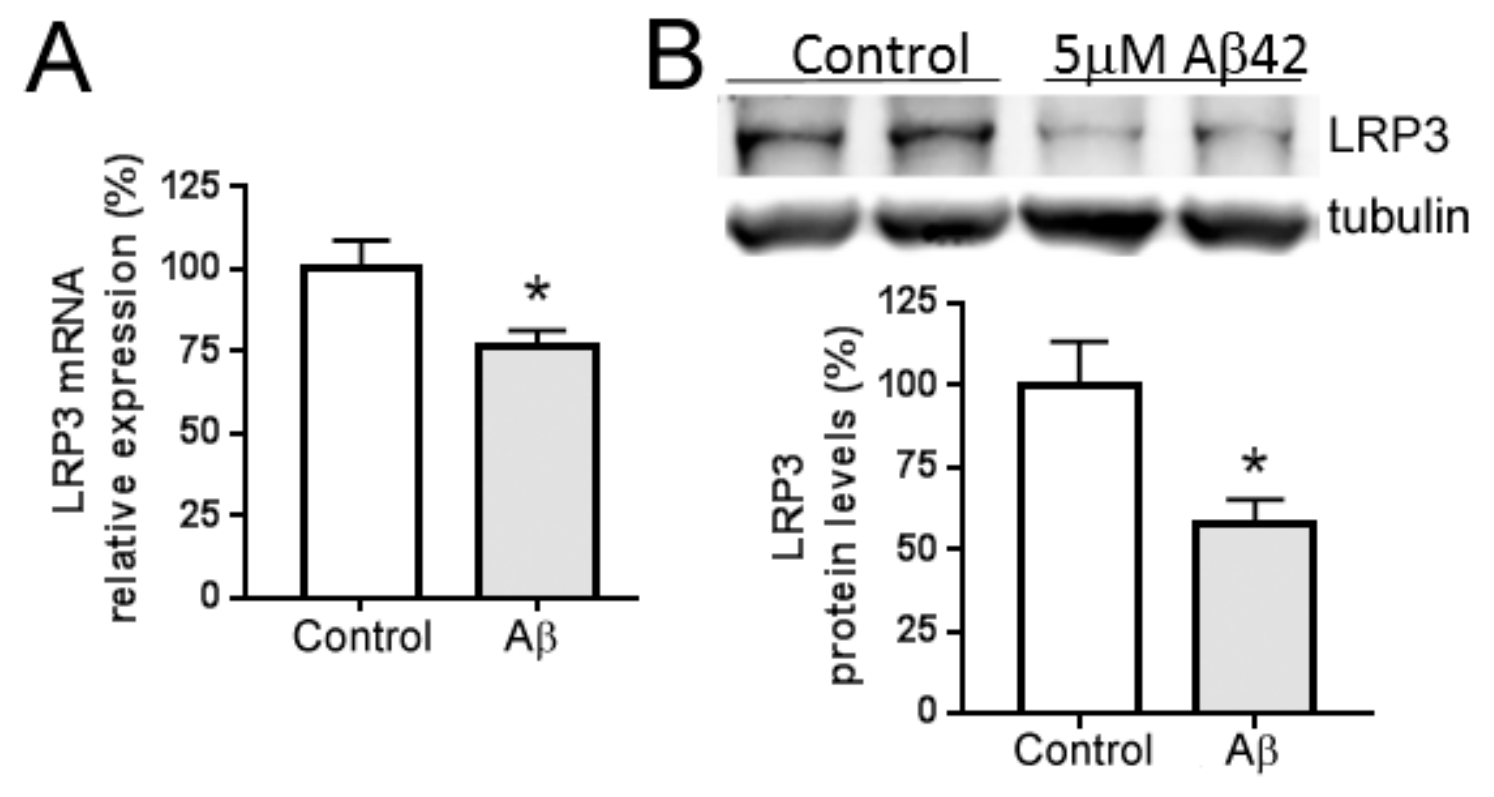

Figure 3

A 42 reduces LRP3 expression a) qRT-PCR analysis showing expression of LRP3 mRNA in neurodifferentiated SH-SYSH cells treated with $5 \mu \mathrm{M} \mathrm{A \beta 42} \mathrm{or} \mathrm{scrambled} \mathrm{A \beta 42} \mathrm{(control).} \mathrm{18S} \mathrm{was} \mathrm{used} \mathrm{as} \mathrm{an}$ internal control for mRNA expression ( $n=8$ for each condition, $p<0.05$; T-test). b) Quantification and western blot showing the expression of LRP3 proteins in neuro-differentiated SH-SYSH cells treated with $5 \mu \mathrm{M} A \beta 42$ or scrambled $A \beta 42$ (control). Tubulin was used as an internal control ( $n=9$ for each condition, ${ }^{*} \mathrm{p}<0.05$, T-test). 


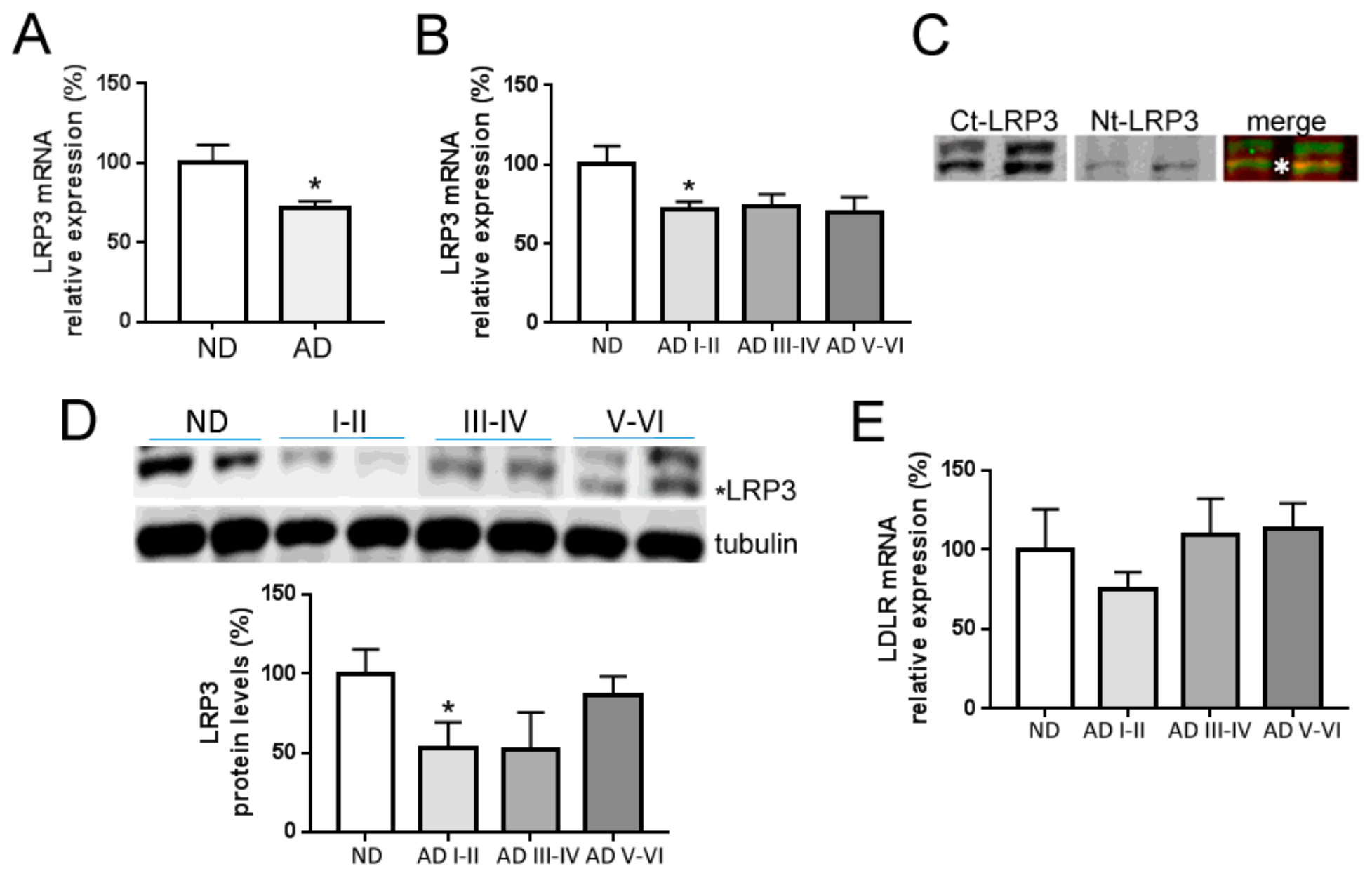

Figure 4

Low levels of LRP3 in AD frontal cortex a) qRT-PCR analysis showing expression of LRP3 mRNA in brain extracts from non-demented (ND) and Alzheimer's disease (AD) subjects, and b) categorized by Braak's stages (I-II, III-IV and V-VI). 18s was used as an internal control for mRNA expression ( $n=9$ for ND, $n=10$ for each AD Braak's stage, * $p<0.05$, T-test; $p=0.065$ for ND v ADIII-IV; $p=0.0545$ for ND $\vee$ ADV-VI). $c$ ) Western blots showing different LRP3 immunoreactivities in human cortex extracts. Two bands were observed using an anti-C-terminal LRP3, but a single band when an anti-N-terminal LRP3 was used, all of them between $70 \mathrm{kDa}$ and $100 \mathrm{kDa}$. One of the bands immunoreacted to both antibodies, likely representing the full-length receptor. Accordingly, the overlapping band $\left.{ }^{*}\right)$ was the selected for quantification. d) Quantification and western blot showing the expression of LRP3 protein in brain extracts from non-demented (ND) and Alzheimer's disease (AD) subjects, categorized by Braak's stages. Tubulin was used as an internal control ( $n=9$ for ND, $n=10$ for each AD Braak's stage, * $p<0.05$, Mann Whitney test. e) qRT-PCR analysis showing expression of LDLR mRNA in brain extracts from nondemented (ND) and Alzheimer's disease (AD) subjects, categorized by Braak's stages. 18s was used as an internal control for mRNA expression ( $n=9$ for ND, $n=10$ for each AD Braak's stage). 


\section{Cx ND}
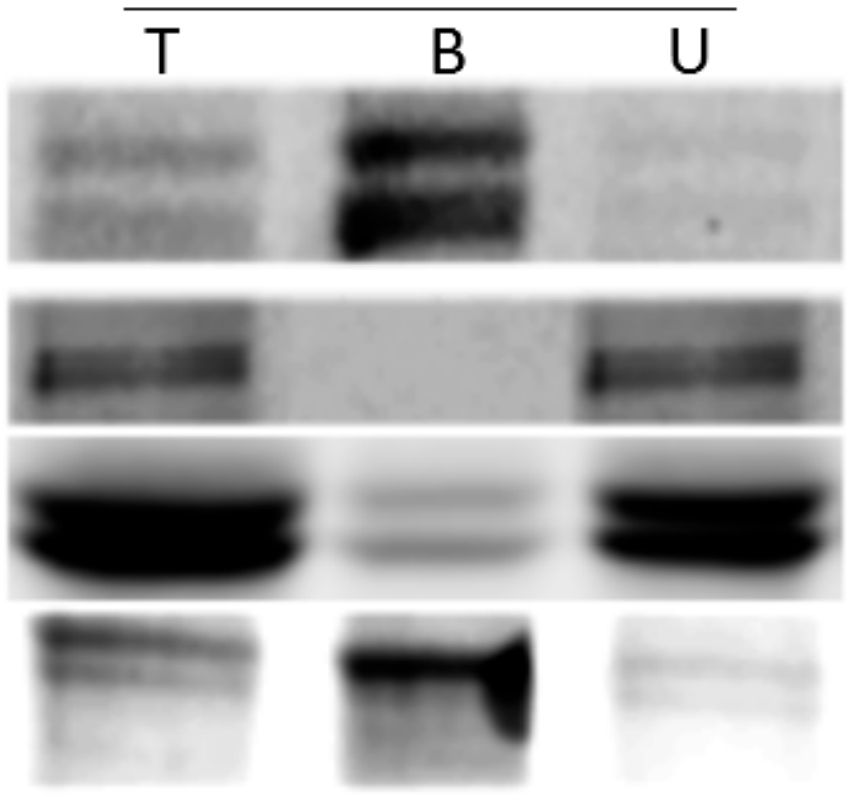

Cx AD

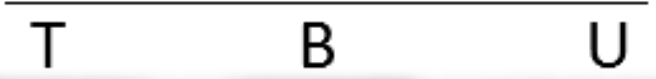

LRP3

reelin

ApoE

APP

\section{Figure 5}

LRP3 co-immunoprecipates with apoE and APP Representative western blots showing immunoprecipitation of LRP3 and co-immunoprecipitation of reelin (no immunoprecipitated), apoE and APP, from non-demented (ND) and Alzheimer's disease (AD) extracts. $T=$ total input, $B=$ bound fraction, $\mathrm{U}=$ unbound fraction.

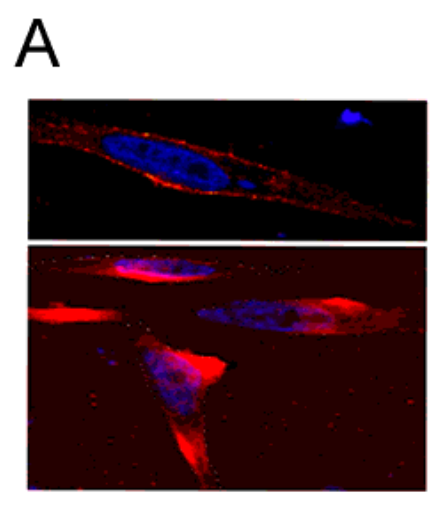

B

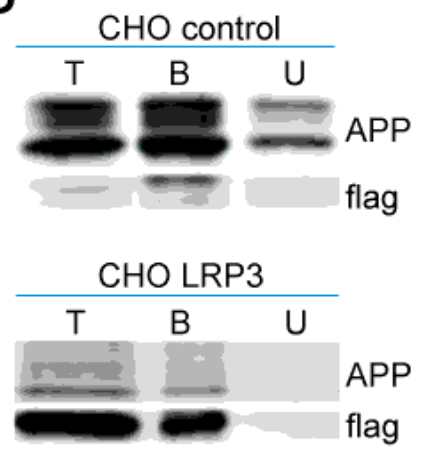

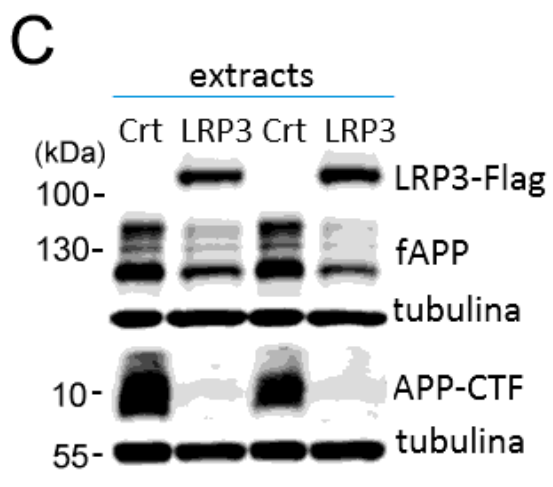

$\mathrm{E}$
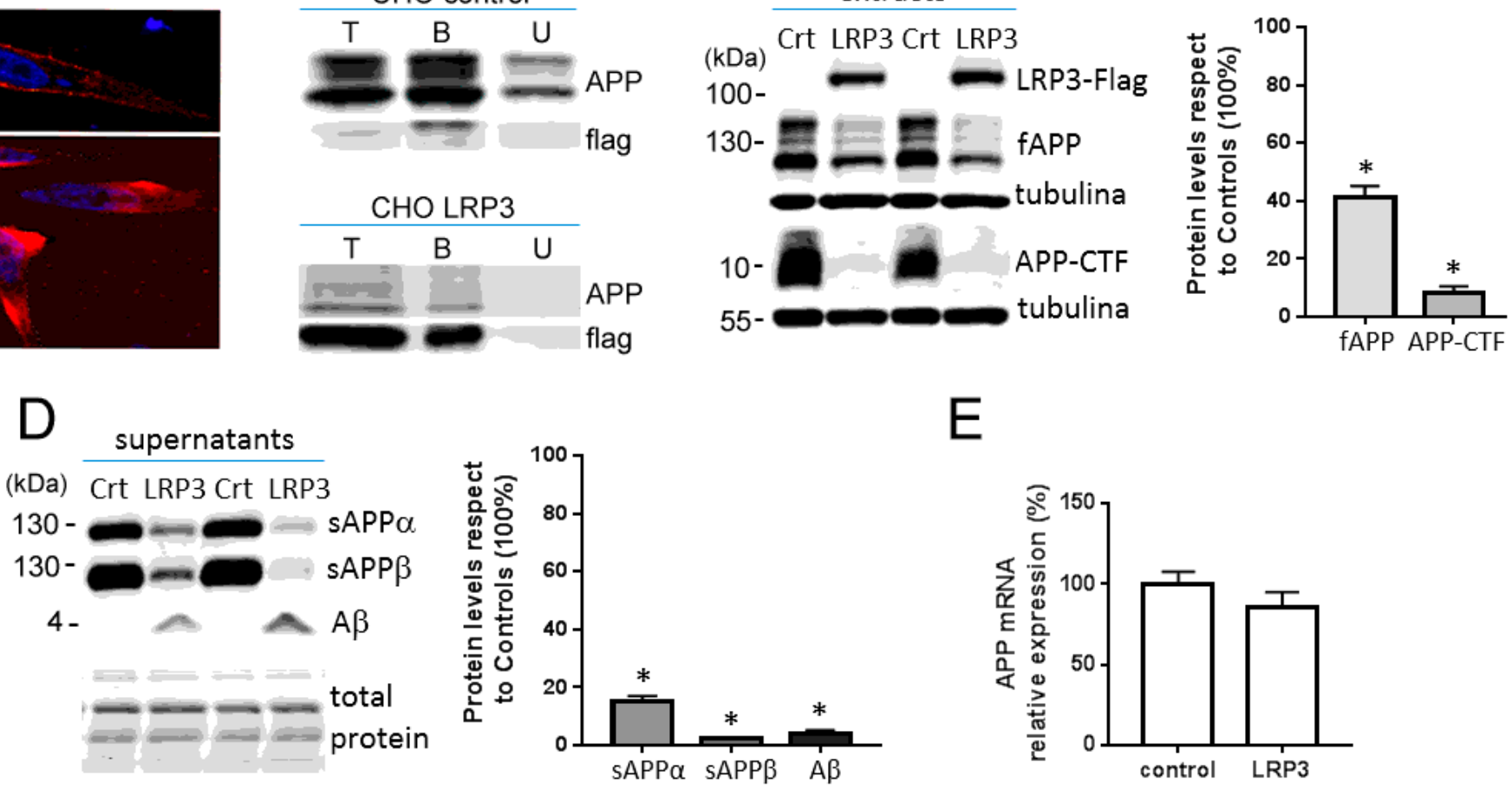

\section{Figure 6}


LRP3 overexpression in CHO-PS70 cells decreases APP levels a) Representative immunofluorescence photomicrographs showing LRP3 labelling at the plasma membrane (upper image) and in discrete areas (bottom image) of CHO-PS70 cells transfected with LRP3-flag cDNA. b) Western blots from CHO-PS70 transfected with LRP3-flag (CHO-LRP3) or pcDNA3.1 (CHO-control) showing immunoprecipitation of APP (using a C-terminal APP antibody) and co-immunoprecipitation of APP (using a N-terminal APP antibody) and LRP3. $T=$ input, $B=$ bound fraction, $\mathrm{U}=$ unbound fraction. $\mathrm{C}$ ) Quantification and western blots from CHO-PS70 transfected with LRP3-flag (LRP3) or pcDNA3.1 (Ctr, control) showing the expression in the cell extracts of LRP3, full-length APP, APP-CTF proteins and tubulin, as an internal control; in the supernatants, western blots show the expression of $S A P P a, S A P P \beta$ and $A \beta$, and the total protein as internal control ( $n=6$ for each condition, ${ }^{*} p<0.001$. $d$ ) qRT-PCR analysis showing expression of APP mRNA in CHO-PS70 transfected with LRP3-flag (LRP3) or pcDNA3.1 (Ctr, control). GAPDH was used as an internal control for mRNA expression ( $n=13$ for each condition).

\section{Supplementary Files}

This is a list of supplementary files associated with this preprint. Click to download.

- CompleteMicroarray.xlsx 